\title{
Assessing range-wide "contribution to recovery" by multiple local governments for a threatened species
}

\author{
Steven E. Greco ${ }^{1}$
}

\begin{abstract}
To recover a threatened or endangered species, numerous local government jurisdictions are usually involved in habitat mitigation and conservation planning actions for evaluating impacts to habitat. In the USA local governments make official land use decisions. A social-ecological case study of multiple counties is presented tabulating the relative "contribution to recovery" by each county for giant garter snake (GGS; Thamnophis gigas), a federally and state-listed threatened California endemic watersnake species that is reliant on rice agriculture. The entire geographic range of the GGS is examined in relation to multiple county boundaries, recovery unit boundaries, federal habitat conservation plan (HCP) coverage, California natural community conservation plan (NCCP) coverage, and piecemeal mitigation (areas lacking formal conservation plans). Results indicate that of the 22 counties that cover the range of the GGS, nine counties have HCPs that cover the species in $38 \%$ of the range and of those nine HCPs six have NCCPs covering $14 \%$ of the range. Thus, more than half of the range (62\%) mitigates for impacts to the GGS in a project-by-project (piecemeal) manner with no HCP, while $24 \%$ of the range has a population jeopardy standard covered by HCPs and $14 \%$ has a population recovery standard covered by NCCPs. However, four of the nine recovery units are substantially covered by HCP or NCCP conservation plans ( 65$81 \%)$, while the remaining five units have far less coverage $(\sim 1-36 \%)$. Ninety-nine percent of all known GGS occurrences were found in Sutter, Sacramento, Yolo, Colusa, Butte, Merced, Glenn, San Joaquin, Fresno, Solano, and Kern counties (n = 85, 55, 51, 44, 36, $27,17,9,9,4,4$, respectively). These 11 counties will play an important role toward contributing to recovery of the GGS. In theory, the variation in different conservation standards over a species' range could have significant implications for its ultimate recovery potential.
\end{abstract}

Key Words: Central Valley; county; giant garter snake; HCP; jeopardy standard; multijurisdictional habitat planning; NCCP; offset; piecemeal mitigation; recovery standard; Thamnophis gigas

\section{INTRODUCTION}

\section{Background}

Mitigation for impacts to endangered species habitat is accomplished using a variety of means including biodiversity offset programs (McKenney and Kiesecker 2010, IUCN 2014). Invariably, endangered species habitat falls into one to multiple governmental jurisdictions depending on the size of the geographic range of the focal organism (Beatley 1994). Typically, in the USA through wildlife agency consultation, mitigation is determined on a project-by-project basis or through formalized conservation plans that predetermine required actions (Presley 2011). Conservation plans may contain many covered species and each endangered species usually has a recovery plan with multiple local government jurisdictions covering its geographic area. Hence, in theory, each jurisdiction plays a part in contributing to the recovery of each special-status species in their geographic area whether covered in a plan or not, through mitigation and conservation actions at the local level. In this paper, I endeavor to quantify and tabulate the relative proportion of this contribution for each local government using a tractable case study of the giant garter snake (Thamnophis gigas), a threatened restricted endemic species in California's Central Valley. To the author's knowledge, little to no work has attempted to elucidate these spatial relationships across the entire range of a listed special-status species.

A habitat conservation plan (HCP) under Section 10 of the USA federal Endangered Species Act (FESA) is an offset program to allow limited "incidental take" from impacts to a listed species' habitat in exchange for habitat mitigation (National Research Council 1995). A related and complementary program in the state of California is a natural community conservation plan (NCCP), established under the Natural Community Conservation Planning Act (NCCPA 1991; passed in 1991 and revised in 2002 and 2003), designed to conserve functioning ecosystems as well as species' habitat (National Research Council 1995, Pollak 2001, Hopkins 2004, Presley 2011). NCCPs require additional conservation actions beyond species mitigation that addresses natural communities potentially affected in the plan area and is an important conservation tool for the California Endangered Species Act (CESA). The U.S. Fish and Wildlife Service (USFWS) or the National Marine Fisheries Service (NMFS) is responsible for negotiating HCPs with local applicants and the California Department of Fish and Wildlife (CDFW) is responsible for NCCPs. These agencies forge a joint conservation agreement and/ or implementation agreement with local planning agencies (or private entities) to implement these respective plans (Hopkins 2004, USFWS and NMFS 2016). In California, HCPs can be associated with an NCCP component added to it or not (National Research Council 1995, Presley 2011). This means that if a local government or group of governments (or private entities) is seeking the benefits of an HCP under federal law, they also have the option to add an NCCP pursuant to California law, but it is not required. An applicant's incentive for adding an NCCP to an HCP is that all state-level consultation, mitigation, and conservation are predetermined over the permit time period as with the HCP on the federal end. Thus, a combined HCP-NCCP provides permit coverage of large areas for all covered species in 
lieu of potentially numerous permits over the same area; this also known as "permit streamlining" (Hopkins 2004, Presley 2011).

The main conservation benefit from the use of HCPs and NCCPs is coordinated mitigation and conservation actions that can result in larger blocks of higher quality and more connected habitats (Noss et al. 1997). Lacking either of these planning approaches forces local governments or private entities to consult and negotiate on a project-by-project basis with each respective agency (both federal and state) and can result in uncoordinated or "piecemeal" conservation (McKenney and Kiesecker 2010:174). From a development perspective, piecemeal conservation can be extremely expensive, time consuming, and lead to great uncertainty and lengthy delay of projects (Scott et al. 2006). From a biological standpoint, there is evidence from Southern California that an HCP combined with an NCCP can result in greatly enhanced conservation outcomes as compared to a piecemeal mitigation approach (Underwood 2011). By comparing two large areas of San Diego County, Underwood (2011) found the portion with a multispecies HCP-NCCP had implemented 5-10 times more area for conservation (in the most important areas) for rare species than in the portion of the county practicing project-by-project (piecemeal) mitigation. The use of HCPs on private lands has also been found to have "positive effects" on endangered species recovery (Langpap and Kerkvliet 2012:15). Recovery and delisting of a threatened or endangered species is the ultimate goal of the FESA and the CESA.

\section{Conservation standards in HCPs and NCCPs: jeopardy versus recovery}

Despite the potential benefits of HCPs there are numerous criticisms leveled against them (Duerksen et al. 1997, Noss et al. 1997, Kareiva et al. 1999, Underwood 2011). One such important concern is the potential for HCPs to undermine recovery efforts. Section 7(a)(2) of the FESA states federal agencies must "insure that any action authorized, funded, or carried out by such agency... is not likely to jeopardize the continued existence of any endangered species or threatened species or result in the destruction or adverse modification of habitat" for the species (16 U.S.C. $§ 1536(a)(2))$. Furthermore, federal regulations define the statement "jeopardize the continued existence of" as engaging "in an action that reasonably would be expected, directly or indirectly, to reduce appreciably the likelihood of both the survival and recovery of a listed species in the wild by reducing the reproduction, numbers, or distribution of that species" (50 C.F. $\mathrm{R}$ §402.02). To constitute "jeopardy" an agency action must severely affect survival and recovery, thus the USFWS interpretation of this statute means "a project that does not appreciably reduce the likelihood of a species' survival may proceed, regardless of its potential impact on recovery. The only projects that may not proceed are those that would imperil both survival and recovery" (Stanford Environmental Law Society 2001:98). Hence, a "jeopardy" conservation standard effectively means survival (Rohlf 1991).

"Survival," i.e., a jeopardy conservation standard, for a species implies an intrinsic population growth rate equal to zero $(r=0)$ that neither increases nor decreases the overall population level, i.e., flat-line or no net loss. On the other hand, a recovery standard for a species implies a positive intrinsic population growth rate $(r$ $>0)$ to increase a threatened or endangered species' overall population to the level of delisting. It can be argued that HCPs and project-by-project (piecemeal) mitigation have, at a minimum, a jeopardy conservation standard (Pollak 2001, Stanford Environmental Law Society 2001, Presley 2011) while NCCPs, after the 2003 NCCPA revision, require a recovery conservation standard (Hopkins 2004, Presley 2011). This legal distinction between survival and recovery has been described as a "semantic conundrum" (Rohlf 2001, Jeffers 2008:466). Nonetheless, theoretically, if an endangered species' entire range or entire recovery area is completely covered by HCPs with a minimal jeopardy conservation standard, recovery of that species could be undermined since the overall population might not ever increase to the level of delisting. However, as Noss et al. (1997:32) point out, there are three possible conservation standards for HCPs "from strong plans that actively contribute to recovery, to no net loss, and to net loss that does not preclude recovery." Thus, technically, there is no one absolute conservation standard for HCPs (depending upon HCP negotiation outcomes) and this can be viewed as paradoxical, yet, it is important to apply the precautionary principle here because of the high risks it imposes (sensu Cooney 2005, Mealy et al. 2005). Because of this uncertainty, I take the approach of assuming HCPs are capable of the latter two standards described by Noss et al. (1997) and therefore need to be accountable for them.

\section{Conservation governance}

Depending on the size of the current or historic geographic range of an endangered species, recovery planning can involve governance by a single local government jurisdiction, e.g., in the case of a highly restricted narrow endemic and rare specialist species, to coordination among numerous levels of governmental organization for a wide-ranging generalist species (including multiple cities, parishes, districts, counties, provinces, states, or countries). An example of the former is Lange's metalmark butterfly (Apodemia morno langei) that exists in just Contra Costa County in California, USA. An example of the latter is grizzly bear (Ursus arctos horribilis) whose historical range covers multiple jurisdictions including multiple counties, states, and countries, e.g., the USA, Canada, and Mexico.

Land use planning decisions in the USA are made and implemented by incorporated cities and by counties, which is referred to as local home rule powers (Duerksen et al. 1997, Theobald et al. 2000, Behan 2006) or "local government sovereignty" (Scott et al. 2006:214). Frequently one or more incorporated cities (municipalities) will team up with their associated county, or multiple counties will collaborate, and form an intergovernmental agreement (IGA) to create a joint powers agency or authority (JPA), such as councils of governments (COGs), to delegate local land use decisions across their respective boundaries for regional governance tasks such as planning for water, transportation, and habitat conservation (Duerksen et al. 1997, Hopkins 2004, Powell 2010). The IGA will specify how representatives from each governmental entity in the JPA or COG, e.g., city council and/or county board of supervisors' members, are appointed and make decisions. At the request of a local planning agency such as a county or JPA, the federal or state wildlife agencies can enter into a conservation agreement to implement conservation plans such as an HCP and/or an NCCP. As mentioned above, if no approved conservation plans exist then these local agencies or private entities must consult with the 
wildlife agencies on a project-by-project basis. By statute it is the responsibility of the wildlife agencies to ensure recovery of endangered species by requiring adequate habitat mitigation and, therefore, local HCPs and/or NCCPs can contribute to larger scale conservation strategies (Beatley 1994:200). Overcoming governance fragmentation to achieve landscape-scale conservation of species and ecosystems across ecoregions is a major challenge for wildlife agencies (Powell 2010).

\section{Overview of giant garter snake life history and conservation status}

The giant garter snake (GGS) was first described by Fitch (1940). It is a medium-sized snake with males averaging $60-70 \mathrm{~cm}$ in length and females averaging $70-80 \mathrm{~cm}$ (USFWS 2017) with a maximum length of $163 \mathrm{~cm}$ (Halstead et al. 2015a). It generally has brown-olive coloration with cream, yellow, or orange dorsal striping and two lateral stripes, but varies geographically. Virtually all of the geographic range of the GGS is within the Central Valley ecoregion of California (Fig. 1). Habitat for the GGS has three components: (1) feeding habitat is primarily tule-cattaildominated (Schoenoplectus spp. and Typha spp.) palustrine freshwater wetlands with the main prey items being fish and amphibians caught in the water, (2) upland riparian habitat near the aquatic habitat used for cover and thermoregulation, and (3) upland refugia in shallow burrows for winter hibernacula habitat for brumation (reptile hibernation) in winter months (Halstead et al. 2015b, USFWS 2017). Reproduction starts with mating in the spring, soon after winter emergence in March, and birth occurs in the summer months in shallow burrows along vegetation covered stream bank edges. The GGS bears live young with an average litter size of 17 to 23 . Home range size varies from 17 to 44 ha (USFWS 2017). Average population densities vary depending on habitat quality but range from 8.0 snakes per ha in high quality habitat to 0.83 snakes per ha in low quality habitat (Wylie et al. 2010). There are nine known populations across its range that correspond to the boundaries of the nine recovery units in the recovery plan (USFWS 2017; see Fig. 2).

The current habitat conditions for the GGS in the Central Valley are much degraded from their historical character (see Site description below). High quality wetlands with all three habitat components are limited in extent and the snake has become reliant on rice agriculture and water delivery and drainage canals to feed and traverse the landscape (Halstead et al. 2019).

In 1971 the GGS was first listed as threatened under the CESA and in 1993 it was federally listed as threatened under the FESA. There are five threat factors listed in the recovery plan: (1) habitat destruction or modification, (2) overutilization, (3) disease and predation, (4) regulatory mechanism inadequacy, and (5) other natural or man-made factors, for instance, rice cultivation fluctuations, water availability, and competition from non-native water snakes (USFWS 2017). The recovery plan for the GGS anticipates delisting by 2047 if recovery criteria are met by that time (USFWS 2017). Although recovery units have been defined in the recovery plan, no critical habitat has been designated thus far.

\section{Research questions and paper objective/purpose}

This paper presents a social-ecological case study of the GGS, a threatened California endemic snake species, examining its entire geographic range in relation to county boundaries, recovery units, HCPs, NCCPs, and project-by-project (piecemeal) mitigation. The variation in different conservation standards over the snake's range could have significant implications for its ultimate recovery.

Fig. 1. The geographic range of giant garter snake (GGS; Thamnophis gigas) and the density of known GGS occurrences (derived from California Natural Diversity Database point data) within the Central Valley ecoregion of the state of California. Numbered counties correspond to Table 1 (the rank order of the percent of range within each respective county). See occurrence data disclaimer in the text.

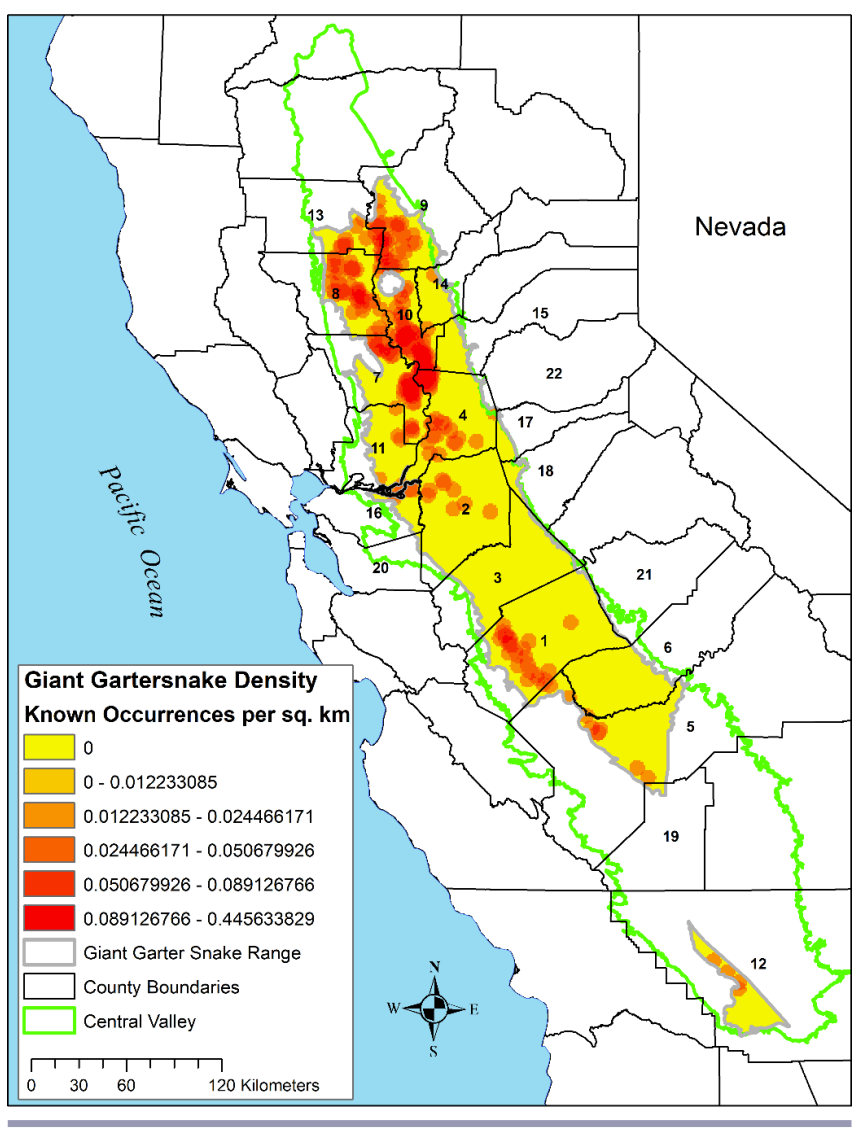

This research is driven by several pragmatic questions regarding the logistics of recovering a special status species in multiple county jurisdictions. The research questions for this study are the following: (1) How can multiple jurisdictions be measured, ranked, and summed-up to assess relative contributions by individual counties to the recovery of the GGS over its entire range or its recovery units? (2) Where are the known occurrences of the GGS (as a rough proxy for population locations)? (3) How many HCPs alone or in combination with NCCPs cover the range of the GGS? (4) Conversely, what percentage of the range of the GGS is not covered by any conservation plans, i.e., subject to project-by-project, or piecemeal, mitigation? (5) What are the conservation standards associated with each mitigation approach and their implications for species recovery? (6) What are the prospects for species recovery of the GGS? 
Fig. 2. Recovery units (numbers correspond to Table 2) for the giant garter snake (GGS; Thamnophis gigas) and the habitat conservation plan and natural community conservation plan footprints (colored fill) within the Central Valley ecoregion of the state of California.

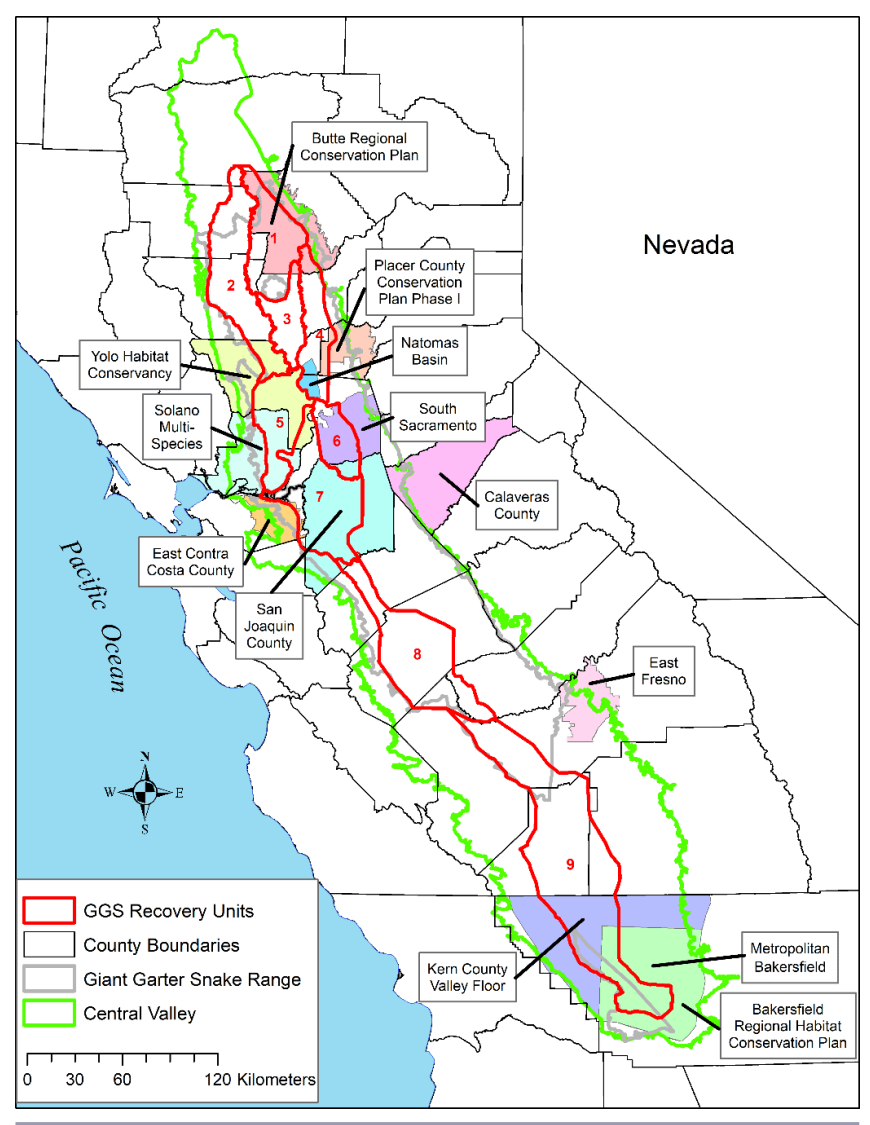

\section{METHODS}

\section{Site description}

The geographic range of the giant garter snake is within the Central Valley ecoregion of California (Fig. 1). The Central Valley is approximately $700 \mathrm{~km}$ in length, $100 \mathrm{~km}$ wide (on average) and $59,561 \mathrm{~km}^{2}$ in area. Given the high-quality soils and low topographic relief, most of the Central Valley has been converted to agricultural and urban land uses with $95 \%$ of the once-extensive natural wetlands and $90 \%$ of riparian areas lost and just 83,000 ha remain of managed wetlands (Central Valley Joint Venture 2006). Many former wetlands were converted to rice production or other crops (Garone 2011). Urban areas are also distributed throughout the valley and are expanding rapidly. The Central Valley has a Mediterranean climate with hot dry precipitationfree summers (with peak temperature reaching 46 degrees Celsius) from June to October and mild cool wet winters (with infrequent frosts) from November to May with an average annual rainfall of $235 \mathrm{~mm}$.

\section{Spatial analyses: range map and recovery units in relation to} counties and plans

Several spatial analyses were conducted using ArcGIS version 10.5.1 (Esri, Redlands, CA). Each geographic information system (GIS) dataset was converted to an Albers projection with North American Datum of 1983.

A digital range map (polygon shapefile) for the GGS was obtained from the California Wildlife Habitat Relationship System GIS database (animal code R79; CDFW 2014). A vector map overlay analysis (Chang 2019) was performed between the range map and a publicly available GIS data layer of the counties in California. The analysis was done using the map extraction tool "Clip" (Chang 2019). This allows for the quantification and tabularization of the percent of land area of the GGS's range contained in each respective county.

Another map overlay procedure was used to create a composite map union (Mitchell 1999, Chang 2019) between the GGS range map, counties, and a polygon shapefile of the conservation plan boundaries of HCPs and NCCPs within the Central Valley ecoregion of California (accessed 14 August 2014 from CDFW at https://map.dfg.ca.gov/metadata/ds0760.html). For this procedure the analysis tool "Union" was employed. This allows for the quantification and tabularization of the percent of the GGS range covered by each conservation plan (HCP and NCCP) within each respective county.

Likewise, a vector map union overlay analysis (Chang 2019) was also conducted between the conservation plan boundaries of HCPs and NCCPs within the Central Valley ecoregion of California and a polygon shapefile of the GGS recovery units (accessed 10 December 2019 from http://www.arcgis.com/home/ item.html $\mathrm{id}=8 \mathrm{~d} 5 \mathrm{f} 37 \mathrm{~cd} 7637448 \mathrm{c} 8 \mathrm{e} 32 \mathrm{ce} 7 \mathrm{aa} 3896463)$. This allows for the quantification and tabularization of land area of each conservation plan (HCP and NCCP) within each respective GGS recovery unit.

Spatial analysis: giant garter snake occurrence density map A raster density map of known occurrences of the GGS was calculated using the spatial analyst tool "Point Density" in ArcGIS (Mitchell 1999, Chang 2019). Note that this is not population density, but rather, occurrence density and each occurrence (data point) can consist of one to numerous sightings of GGS individuals. The cell size was set to $1 \mathrm{~km}$ and the search radius was set to $5 \mathrm{~km}$ (the area of approximately 15 nonoverlapping home ranges). The resulting raster surface represents units of known GGS occurrences per square kilometer and the surface was classified using quantiles with six classes. The point data of known GGS occurrences were obtained from the California Natural Diversity Database (CNDDB), which has spatial accuracies ranging approximately from 160 to $1600 \mathrm{~m}$ (CNDDB 2011). The CNDDB point data are intentionally degraded in spatial accuracy to protect location identity. This map was generated to determine the frequency of occurrences in each county jurisdiction and for heuristic value to view the areas within the county jurisdictions of relatively high and low density.

To determine the frequency of GGS occurrences contained in each respective county a spatial join procedure was performed (Chang 2019). Using the vector map overlay tool "Spatial Join" the CNDDB occurrence points were overlaid on the vector county 
map layer to derive an occurrence frequency count for tabularization of each county.

\section{RESULTS}

Spatial analyses: range map and recovery units in relation to counties and plans

The entire geographic range of the GGS is covered by 22 counties within the Central Valley of California (Table 1, Figs. 1 and 3). Almost $98 \%$ of the range is found in 16 counties and $89 \%$ is within 12 counties. Of the 22 counties that cover the range of the GGS, only nine counties have HCPs that address the species (in $38.2 \%$ of the range) and of those nine HCPs only five include NCCPs (covering 14\% of the range). Thus, in more than half of the range $(61.8 \%)$, impacts to the GGS are mitigated in a project-by-project (piecemeal) fashion with no HCP, while $24.2 \%$ of the range is covered by HCPs and just $14.0 \%$ has a population recovery standard covered by NCCPs (Fig. 4). Importantly, $86 \%$ of the range has a population jeopardy standard, where no actions to improve the species' threat status are necessarily required as part of a habitat mitigation action.

Fig. 3. Counties are listed in rank order (high to low) of the percent of giant garter snake (Thamnophis gigas) geographic range contained within each county (red bars). The number of known occurrences in each county are also shown (white bars). Note that Stanislaus and Madera counties have no known occurrences despite possessing (containing) a significant amount of range.

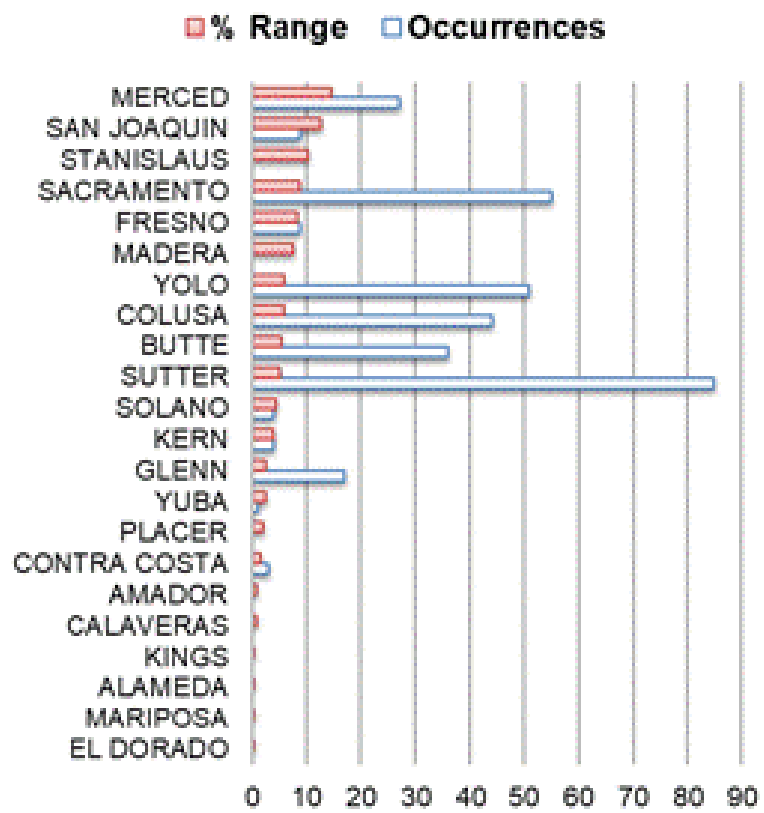

The recovery unit analysis (Table 2, Fig. 2) reveals that four of the nine recovery units are substantially covered by HCP or NCCP conservation plans $(65-81 \%)$, while the remaining five units have far less coverage $(1-36 \%)$. On average less than half $(43 \%)$ of the recovery units are covered by conservation plans (Table 2). Only two recovery units are substantially covered by NCCP conservation plans (53-65\%) and five others to a lesser degree (8$21 \%$ ) and two have no coverage. Two recovery units have substantial coverage by only HCPs $(69-82 \%)$ while four recovery units have far less HCP-only coverage (1-22\%). Five of the nine recovery units substantially lack any conservation plan coverage (66-99\%) while four moderately lack coverage (18-35\%).

Fig. 4. Percentages of each (minimal) conservation standard over the entire geographic range of the giant garter snake (Thamnophis gigas).

\section{Percent of Range}

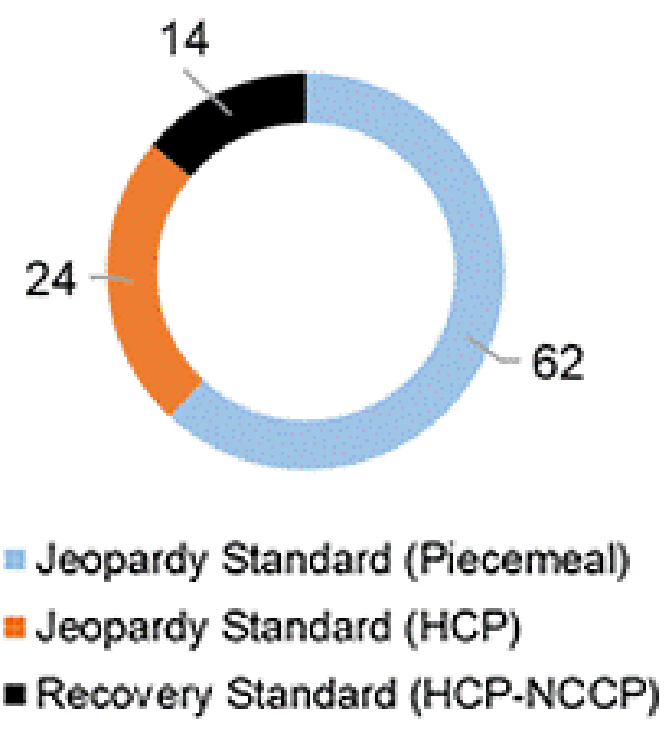

Spatial analysis: giant garter snake occurrence density map The GGS occurrence density map (Fig. 1) shows the relative distribution of all observations $(n=345)$ in each county. The frequency of GGS occurrences for each county is shown in Table 1. In rank order, the highest number of occurrences, or $91 \%$ of all occurrences, were found in seven counties: Sutter, Sacramento, Yolo, Colusa, Butte, Merced, and Glenn counties ( $\mathrm{n}=85,55,51$, $44,36,27,17$, respectively). These are followed by San Joaquin, Fresno, Solano, and Kern counties containing $8 \%$ of all occurrences $(n=9,9,4,4$, respectively). Together these 11 counties represent $99 \%$ of the known occurrences.

Use of CNDDB data requires a disclaimer statement (CNDDB 2011:9): “CNDDB version 09/2015. Please note: The occurrences shown on this map [in Fig. 1] represent the known locations of the species listed here as of the date of this version. There may be additional occurrences or additional species within this area which have not yet been surveyed and/or mapped. Lack of information in the CNDDB about a species or an area can never be used as proof that no special status species occur in an area."

\section{DISCUSSION}

\section{Contribution to recovery}

This study quantifies and tabulates the relative contribution to recovery for the GGS by all counties over its entire geographic range. For the purpose of this discussion I define the concept of "contribution to recovery" using various criteria to illustrate and 
Table 1. A summary table of the counties containing the giant garter snake's (GGS; Thamnophis gigas) geographic range listed in rank order from largest to smallest percent area. Also shown are the habitat conservation plans (HCPs), natural community conservation plans (NCCPs), and the frequency of known occurrences of the GGS (from the California Natural Diversity Database). Rank numbers correspond to Figure 1.

\begin{tabular}{|c|c|c|c|c|c|c|c|c|}
\hline Rank & $\begin{array}{l}\text { County } \\
\text { Name }\end{array}$ & $\begin{array}{l}\text { Area of } \\
\text { Range } \\
\text { (ha) }\end{array}$ & $\begin{array}{l}\text { Percent of } \\
\text { Range in } \\
\text { County }\end{array}$ & $\begin{array}{l}\text { Percent of } \\
\text { Range in } \\
\text { HCP }\end{array}$ & $\begin{array}{l}\text { Percent of } \\
\text { Range in } \\
\text { NCCP }\end{array}$ & $\begin{array}{l}\text { Known } \\
\text { Occurrences } \\
\text { in County }\end{array}$ & $\begin{array}{l}\text { GGS } \\
\text { covered in } \\
\text { Plan(s) }\end{array}$ & Notes \\
\hline 1 & Merced & $400,372.9$ & 14.6 & 0 & 0 & 27 & & \\
\hline 2 & San Joaquin & $346,712.6$ & 12.6 & 12.2 & 0 & 9 & yes & San Joaquin County HCP \\
\hline 3 & Stanislaus & $281,445.4$ & 10.3 & 0 & 0 & 0 & & \\
\hline 4 & Sacramento & $243,018.9$ & 8.9 & 4.9 & 0 & 55 & yes & $\begin{array}{l}\text { Two HCPs in county: Natomas Basin HCP, } \\
\text { South Sacramento HCP }\end{array}$ \\
\hline 5 & Fresno & $232,080.5$ & 8.5 & 0.002 & 0 & 9 & no & No occurrences in East Fresno HCP \\
\hline 6 & Madera & $210,474.1$ & 7.7 & 0.0 & 0 & 0 & & \\
\hline 7 & Yolo & $167,022.7$ & 5.9 & 5.9 & 5.9 & 51 & yes & Yolo Habitat Conservancy HCP/NCCP \\
\hline 8 & Colusa & $159,370.7$ & 5.8 & 0 & 0 & 44 & & \\
\hline 9 & Butte & $146,279.8$ & 5.3 & 5.1 & 5.1 & 36 & yes & $\begin{array}{l}\text { Butte Regional Conservation Plan HCP/ } \\
\text { NCCP }\end{array}$ \\
\hline 10 & Sutter & $141,659.2$ & 5.2 & 0.2 & 0 & 85 & yes & Natomas Basin HCP \\
\hline 11 & Solano & $120,359.6$ & 4.4 & 4.2 & 0 & 4 & yes & Solano Multi-Species HCP \\
\hline 12 & Kern & $108,610.6$ & 3.8 & 3.2 & 0.6 & 4 & yes & $\begin{array}{l}\text { Two HCPs in county: Kern County Valley } \\
\text { Floor HCP ( } 3 \text { occurrences), Metropolitan } \\
\text { Bakersfield HCP/NCCP ( } 1 \text { occurrence })\end{array}$ \\
\hline 13 & Glenn & $70,067.3$ & 2.6 & 0 & 0 & 17 & & \\
\hline 14 & Yuba & $67,744.0$ & 2.5 & 0 & 0 & 1 & & \\
\hline 15 & Placer & $56,016.1$ & 2.0 & 1.5 & 1.5 & 0 & yes & $\begin{array}{l}\text { Placer County Conservation Plan HCP/ } \\
\text { NCCP Phase } 1\end{array}$ \\
\hline 16 & Contra Costa & $44,281.8$ & 1.6 & 0.9 & 0.9 & 3 & yes & $\begin{array}{l}\text { Only one occurrence is in East Contra Costa } \\
\text { HCP/NCCP area }\end{array}$ \\
\hline 17 & Amador & $23,107.3$ & 0.8 & 0 & 0 & 0 & & \\
\hline 18 & Calaveras & $21,452.7$ & 0.8 & 0 & 0 & 0 & no & Multiple HCPs in county; none cover GGS \\
\hline 19 & Kings & 7060.1 & 0.3 & 0 & 0 & 0 & & \\
\hline 20 & Alameda & 3228.5 & 0.1 & 0 & 0 & 0 & & \\
\hline 21 & Mariposa & 2285.8 & 0.1 & 0 & 0 & 0 & & \\
\hline 22 & $\begin{array}{l}\text { El Dorado } \\
\text { TOTAL }\end{array}$ & $\begin{array}{c}243.1 \\
2.852 .893 .7\end{array}$ & $\begin{array}{c}0.009 \\
100\end{array}$ & $\begin{array}{c}0 \\
38.2\end{array}$ & $\begin{array}{c}0 \\
14.0\end{array}$ & $\begin{array}{c}0 \\
345\end{array}$ & & \\
\hline
\end{tabular}

explore different aspects of the concept. The existing literature base lacks formal definitions for this concept. The first definition is presented as a two-part hierarchy: the first part defines "contribution to recovery" as a county's possession (or containment) of a high density of known occurrences (Table 1), and second, as a county's possession (or containment) of a significant portion of its range (Table 1). Using the first criterion it is fairly clear that the 11 counties identified as containing $99 \%$ of the known occurrences are critically important contributors to the recovery of the GGS.

However, using the second criterion, it is less clear how to prioritize the counties because of several counties having a large portion of the range, but lacking known occurrences, perhaps resulting from habitat conversions and/or population extirpation. For example, Stanislaus and Madera counties (in the San Joaquin Recovery Unit) rank third and sixth (out of 22) in terms of possession (or containment) of range, but have little to no known GGS occurrences. According to the GGS recovery plan these counties will play an important future role for the goal to connect the northern populations to the isolated southern populations (USFWS 2017). An analysis of suitable habitat in these two counties would have to be conducted to determine whether extirpation versus lack of suitable habitat is the cause of the lack of GGS occurrences (which is beyond the scope of this study).
Therefore, the county's containment of range may be dependent on whether suitable habitat exists or not. If habitat does exist then reintroduction may be a viable option (it should be noted that the San Joaquin Recovery Unit is prioritized for GGS reintroduction in the recovery plan [USFWS 2017]) and if habitat does not exist then ecological restoration of GGS habitat would be needed to contribute to recovery in these two counties. This points to a major limitation of the containment of range as a sole criterion for contribution to recovery. Containment of "critical habitat" is likely to be a better assessment method, however, as discussed in the introduction above, no critical habitat has yet been designated for the GGS by the USFWS.

Another definition of "contribution to recovery" is a county's containment of range in relation to formal conservation plan coverage (or lack thereof). Table 1 shows that $38 \%$ of the GGS range has a formal conservation plan, but only $14 \%$ is covered by plans with a recovery standard, i.e., HCP-NCCP. The fact that presently only $14 \%$ of the GGS range has a recovery conservation standard officially designated for it could have significant theoretical implications for its ultimate recovery potential. Of greatest concern are the rural counties of Merced and Colusa that contain significant range and known occurrences, but that have no formal conservation plans and rely on project-by-project mitigation practices. Ideally these counties would be candidates 
Table 2. Recovery units for the giant garter snake (Thamnophis gigas) with the habitat conservation plans (HCPs) and natural community conservation plans (NCCPs) that cover each unit. The recovery unit number corresponds with Figure 2.

\begin{tabular}{|c|c|c|c|c|c|c|c|}
\hline $\begin{array}{l}\text { Recovery } \\
\text { Unit } \\
\text { Number }\end{array}$ & $\begin{array}{l}\text { Recovery Unit } \\
\text { Name }\end{array}$ & $\begin{array}{l}\text { Recovery } \\
\text { Unit Area } \\
\text { (ha) }\end{array}$ & $\begin{array}{l}\text { Number of Plans and } \\
\text { Name of Plans Covering the Unit }\end{array}$ & $\begin{array}{l}\text { Percent of Unit } \\
\text { Covered by } \\
\text { Plans }\end{array}$ & $\begin{array}{l}\text { Percent of Unit } \\
\text { Covered by } \\
\text { NCCP }\end{array}$ & $\begin{array}{l}\text { Percent of Unit } \\
\text { Covered by } \\
\text { HCP only }\end{array}$ & $\begin{array}{l}\text { Percent of Unit } \\
\text { Not Covered by } \\
\text { a Plan }\end{array}$ \\
\hline 1 & Butte Basin & $193,974.0$ & (1): Butte $\mathrm{HCP} / \mathrm{NCCP}$ & 64.7 & 64.7 & 0 & 35.3 \\
\hline 2 & Colusa Basin & $274,198.0$ & (1): Yolo HCP/NCCP & 13.6 & 13.6 & 0 & 86.4 \\
\hline 3 & Sutter Basin & $97,610.2$ & (1): Butte $\mathrm{HCP} / \mathrm{NCCP}$ & 7.6 & 7.6 & 0 & 92.4 \\
\hline 4 & American Basin & $146,801.0$ & $\begin{array}{c}\text { (3): Butte HCP/NCCP, Placer HCP/ } \\
\text { NCCP, Natomas HCP }\end{array}$ & 36.1 & 21.4 & 14.6 & 73.9 \\
\hline 5 & Yolo Basin & $168,371.0$ & (2): Yolo HCP/NCCP, Solano HCP & 74.4 & 52.6 & 21.8 & 25.6 \\
\hline 6 & $\begin{array}{l}\text { Cosumnes- } \\
\text { Mokelumne Basin }\end{array}$ & $97,901.9$ & $\begin{array}{c}\text { (2): South Sacramento HCP, San } \\
\text { Joaquin HCP }\end{array}$ & 81.1 & 0 & 81.8 & 18.2 \\
\hline 7 & Delta Basin & $284,493.0$ & $\begin{array}{l}\text { (3): San Joaquin HCP, Yolo HCP/ } \\
\text { NCCP, } \\
\text { Solano HCP, E. Contra Costa HCP/ } \\
\text { NCCP }\end{array}$ & 77.2 & 8.3 & 68.9 & 22.8 \\
\hline 8 & San Joaquin Basin & $325,372.0$ & (1): San Joaquin HCP & 0.9 & 0 & 0.9 & 99.1 \\
\hline 9 & Tulare Basin & $697,100.0$ & (2): Kern HCP, Bakersfield HCP/NCCP & 34.2 & 15.7 & 18.5 & 65.8 \\
\hline TOTAL & & $2,285,821.1$ & $\begin{array}{c}\text { Mean }= \\
\text { SE }=\end{array}$ & $\begin{array}{l}43.3 \\
10.6\end{array}$ & $\begin{array}{c}20.4 \\
7.6\end{array}$ & $\begin{array}{l}22.9 \\
10.4\end{array}$ & $\begin{array}{l}50.5 \\
11.8\end{array}$ \\
\hline
\end{tabular}

for assistance to create HCP-NCCPs covering the GGS, such that mitigation and conservation actions can be coordinated and maximized, however, these rural counties may not accept federal assistance because of historical distrust and this could be counterproductive because of socio-political biases (e.g., Baldwin and Judd 2010). Overcoming mistrust through open and direct public involvement is critical to successful multijurisdictional governance (Powell 2010). In addition to a potential lack of political will, rural counties may also lack the funds, the community expertise, development pressure, or time to create such conservation plans; HCP-NCCPs in California on average take six years to complete and can be expensive (Presley 2011).

A further potential definition of "contribution to recovery" involves the different population conservation standards associated with conservation plans (or lack thereof) covering the nine recovery units. Because an NCCP has a recovery conservation standard, combined HCP-NCCP plans can be assumed to contribute to recovery more so than HCPs alone or project-by-project mitigation. In this respect, in rank order the recovery units 1 and 5 have greater than 50\% (53-65\%; Table 2) coverage by HCP-NCCPs implying the greatest potential contribution to recovery. These are followed (in rank order) by recovery units 4,9 , and 2 (with $14-21 \%$ coverage by HCP-NCCPs; Table 2). Of greatest concern are recovery units 8,3 , and 2 that have the highest percentage of the units not covered by any formal conservation plans (86-99\%; Table 2).

\section{Conservation planning implications and prospects for recovery}

A key to the successful recovery of the GGS is habitat restoration and habitat connectivity for gene flow, especially between the northern and isolated southern populations (USFWS 2017). These are difficult prospects because of intensive landscape fragmentation from large-scale natural wetland conversions (in the 19th and 20th centuries) to agriculture throughout the Central Valley (Garone 2011). However, extensive agricultural water canal systems for both water delivery and field drainage are highly abundant and utilized by the GGS to feed and traverse the landscape (Halstead et al. 2019). In this regard an important consideration is habitat quality versus quantity where an abundance of sink habitat, i.e., the mortality rate exceeds the birth rate, is unlikely to allow recovery of an endangered species (Noss et al. 1997). Clearly, the GGS natural wetlands with suitable upland characteristics are in short supply in the highly modified, agriculturally dominated Central Valley; however, rice agriculture is quite abundant in areas dominated by fine-grained soils of former wetlands. As mentioned above, the GGS has been described as a conservation-reliant species on rice agriculture (Halstead et al. 2019). Conservation-reliant species are those that require human intervention and management in perpetuity (Scott et al. 2010). Unfortunately, rice agriculture is suboptimal habitat, and can act as a sink, but it is essential for survival of the GGS (USFWS 2017, Halstead et al. 2019).

This apparent reliance of the GGS on rice agriculture is, potentially, further complicated by the global economics of rice as a commodity and the viability of the rice industry in California. If global markets for California rice collapse or extended droughts from climate change limit water distribution for growing rice, it could imperil the survival and recovery of the GGS, and therefore uncertainty is a reality for this threatened species.

However, the role of conservation banks could also be expanded to augment recovery for the GGS in key areas of conservation concern in the Central Valley (Bunn et al. 2013). A conservation bank is a government-authorized biodiversity off-set program that conserves habitat in perpetuity and allows private or public land owners of the bank to sell credits to land developers seeking to mitigate impacts for their projects on endangered species habitat (Bunn et al. 2013).

Connecting the northern and southern GGS populations will likely require extensive habitat restoration and specialized canal management to maintain suitable habitat in the intervening counties where the GGS is currently extirpated and suitable habitat exists (e.g., Stanislaus, Madera, and Kings counties; Table 1, Fig. 1). High mortality can be associated with routine agricultural (irrigation and drainage) canal maintenance to 
remove vegetation and sediment and the frequent decommissioning of canals and filling them with soil also results in significant loss of feeding and movement habitat; canal dynamics need further study in the future (personal communication, R. Hill, CDFW, 2016).

Larger channels used for flood control are also utilized by the GGS, such as the Yolo Bypass (in recovery unit 5; see Fig. 2) and the Sutter Bypass (in recovery unit 3). These channels, though highly suitable habitat in the dry season or during extended droughts, are potential sink habitat in the wet season during high flow events if flood waters inundate brumation burrows. The recovery plan states these bypass channels are unsuitable habitat for this reason (USFWS 2017), however, if upland islands can be built within these channels as refugia above the floodwaters it could add substantial new habitat (see Greco and Larsen 2014). The Central Valley Flood Protection Plan is committed to expanding the capacity of the Yolo Bypass in the future, which will substantially lower flood stages in these flood control channels (CDWR 2017).

Other future threats include water availability during drought (Rose et al. 2018), rice field dynamics, i.e., fallowing or crop conversion, and seasonal mistiming of water distribution (USFWS 2017). Although the recovery plan downplays the significance of mortality due to road kill, in a recent study the GGS scored one of the highest road risk scores because it moves short distances between habitat areas in agricultural and urban areas, and therefore road barriers are recommended (Brehme et al. 2018). Another potential significant future threat is competition from an invasive exotic watersnake, Nerodia sipedon (northern watersnake), that recently was detected in Northern California (USFWS 2017; https://www.wildlife.ca.gov/Conservation/ Invasives/Species/Northern-Watersnake). Future management and monitoring of the GGS should consider the use of eDNA for its efficiency and cost savings because a recent successful protocol was developed by Schumer et al. (2019) despite previous unsuccessful attempts (Halstead et al. 2017).

To aid in the recovery of the GGS, additional research should answer the following questions: How can the northern populations be connected with the southern populations? Is there natural infrastructure for a habitat connectivity network or are canals and rice fields necessary? How do agricultural canals play a role in dispersal to natural wetlands? What are the dynamics of canals in the Central Valley? How stable are canals in terms of persistence in time? These are important questions that could reveal valuable best management practices.

\section{CONCLUSION}

Recovering an endangered species in a multiscale and multijurisdictional social-ecological system can be a complex task involving a mix of knowledge and processes from fields such as biology, ecology, land management, planning, policy (law and regulations), economics, and governance combined with a mosaic of myriad spatial relations (Powell 2010). In this study, I attempt to break down this spatial complexity using a tractable case study (a geographic range that is not too big and not too small) to examine which local governments, i.e., counties, are ultimately contributing to recovering an endangered species.

Some key points raised in this paper are worth noting with regard to contribution to recovery by local governments. Depending on the size of the geographic range of an endangered species, conservation governance can become fragmented by political boundaries. A species with a large range could have many such entities. Each local government may or may not have a formal conservation plan such as an HCP, or NCCP (in California), because of expense and time; this roadblock must be reduced. As in the case of the GGS, these plans can have a variety of conservation standards associated with them, ranging from a "recovery standard" (requiring positive population growth rates) to jeopardy with no net loss (zero population growth) or jeopardy with net loss (negative population growth rates) but does not preclude recovery. The jeopardy standard needs to be revisited and legally strengthened to avoid the "semantic conundrum" identified by Rohlf (2001). Theoretically, if a species' entire range is covered by a low jeopardy standard then recovery could be precluded. Assessing a local government's contribution to recovery could consider a number of approaches including containment of range, containment of known occurrences, or containment of critical habitat (if designated).

Assessing holistic management of endangered species to coordinate multijurisdictional conservation appears to be in its infancy. Ideally, at a minimum, each governmental agency, e.g., counties in the USA, contributing to recovery of an endangered species should coordinate with neighboring entities to avoid governance fragmentation. Ultimately, governance coordination needs to occur across entire ecoregions (Powell 2010).

A larger question remains as to whether biodiversity offset programs are ultimately effective as a long-term conservation strategy. Internationally, best management practices for biodiversity offset programs are greatly needed to achieve meaningful conservation results and honest accounting (IUCN 2014).

Responses to this article can be read online at: http://www.ecologyandsociety.org/issues/responses. php/11802

\section{Acknowledgments:}

This work was supported by the USDA National Institute of Food and Agriculture, Hatch Project 1011533. I thank R. Hill for sharing his field knowledge of giant garter snakes and their habitat. A special thanks to D. Bunn, J. Hopkins, and C. Roberts for reviewing earlier versions of this manuscript. The final version of this manuscript was greatly improved by two anonymous reviewers.

\section{Data Availability Statement:}

The data that support the findings of this study are openly available in Dryad at https:/ldoi.org/10.25338/B82P7N.

\section{LITERATURE CITED}

Baldwin, E. D., and R. W. Judd. 2010. Why history matters in conservation planning. Pages 33-52 in S. C. Trombulak and R. F. Baldwin, editors. Landscape-scale conservation planning. Springer, New York, New York, USA. https://doi. org/10.1007/978-90-481-9575-6_3 
Beatley, T. 1994. Habitat conservation planning: endangered species and urban growth. University of Texas Press, Austin, Texas, USA.

Behan, M. 2006. County conservation planning. Pages 156-160 in D. D. Goble, J. M. Scott, and F. W. Davis, editors. The Endangered Species Act at thirty. Volume 1. Island, Covelo, California, USA.

Brehme, C. S., S. A. Hathaway, and R. N. Fisher. 2018. An objective road risk assessment method for multiple species: ranking 166 reptiles and amphibians in California. Landscape Ecology 33:911-935. https://doi.org/10.1007/s10980-018-0640-1

Bunn, D., M. Lubell, and C. K. Johnson. 2013. Reforms could boost conservation banking by landowners. California Agriculture 67(2):86-95. https://doi.org/10.3733/ca.v067n02p86

California Department of Fish and Wildlife (CDFW). 2014. California Wildlife Habitat Relationships (CWHR) Version 9.0 personal computer program. Sacramento, California, USA. [online] URL: https://www.wildlife.ca.gov/Data/CWHR

California Department of Water Resources (CDWR). 2017. Central Valley flood protection plan 2017 update. Department of Water Resources, State of California Resources Agency, Sacramento, California, USA.

California Natural Diversity Database (CNDDB). 2011. CNDDB data use guidelines. California Department of Fish and Wildlife, Sacramento, California, USA. [online] URL: https://nrm.dfg.ca. gov/FileHandler.ashx? DocumentID $=27285 \&$ inline

Central Valley Joint Venture. 2006. Central Valley joint venture implementation plan - conserving bird habitat. U.S. Fish and Wildlife Service, Sacramento, California, USA.

Chang, T. K. 2019. Introduction to geographic information systems. Ninth edition. McGraw Hill, New York, New York, USA.

Cooney, R. 2005. From promise to practicalities: the precautionary principle in biodiversity conservation and sustainable use. Pages 3-17 in R. Cooney and B. Dickson, editors. Biodiversity and the precautionary principle: risk, uncertainty and practice in conservation and sustainable use. Earthscan, London, UK. https://doi.org/10.4324/9781849770583

Duerksen, C. J., D. L. Elliott, N. T. Hobbs, E. Johnson, and J. R. Miller. 1997. Habitat protection planning: where the wild things are. Report Number 470/471. American Planning Association, Planning Advisory Service, Chicago, Illinois, USA.

Fitch, H. S. 1940. A biogeographical study of the ordinoides Artenkreis of garter snakes (genus Thamnophis). University of California Publications in Zoology 44:1-150.

Garone, P. 2011. The fall and rise of wetlands of California's Great Central Valley. University of California Press, Berkeley, California, USA. https://doi.org/10.1525/9780520948495

Greco, S. E., and E. W. Larsen. 2014. Ecological design of multifunctional open channels for flood control and conservation planning. Landscape and Urban Planning 131:14-26. https://doi. org/10.1016/j.landurbplan.2014.07.002

Halstead, B. J., J. P. Rose, G. A. Reyes, G. D. Wylie, and M. L. Casazza. 2019. Conservation reliance of a threatened snake on rice agriculture. Global Ecology and Conservation 19:e00681. https://doi.org/10.1016/j.gecco.2019.e00681

Halstead, B. J., S. M. Skalos, G. D. Wylie, and M. L. Casazza. 2015b. Terrestrial ecology of semi-aquatic giant garter snakes (Thamnophis gigas). Herpetological Conservation and Biology 10 (2):633-644.

Halstead, B. J., D. A. Wood, L. Bowen, S. C. Waters, A. G. Vandergast, J. S. Ersan, S. M. Skalos, and M. L. Casazza. 2017. An evaluation of the efficacy of using environmental DNA ( $e D N A)$ to detect giant garter snakes (Thamnophis gigas). Open-File Report 2017-1123. U.S. Geological Survey, Reston, Virginia, USA. https://doi.org/10.3133/ofr20171123

Halstead, B. J., G. D. Wylie, and M. L. Casazza. 2015a. Literature review of giant garter snake (Thamnophis gigas) biology and conservation. Open-File Report 2015-1150. U.S. Geological Survey, Reston, Virginia, USA. http://dx.doi.org/10.3133/ ofr20151150

Hopkins, J. 2004. Regional conservation planning in California: a guide. Institute for Ecological Health, Davis, California, USA. [online] URL: http://conservationplanning.info/wp-content/ uploads/2019/03/CPGUIDE.pdf

International Union for the Conservation of Nature (IUCN). 2014. Biodiversity offsets technical study paper. IUCN, Gland, Switzerland.

Jeffers, J. 2008. Reversing the trend towards species extinction, or merely halting it? Incorporating the recovery standard into ESA Section 7 jeopardy analyses. Ecology Law Quarterly 35 (3):455-489.

Kareiva, P., S. Andelman, D. Doak, B. Elderd, M. Groom, J. Hoekstra, L. Hood, F. James, J. Lamoreux, G. LeBuhn, C. McCulloch, J. Regetz, L. Savage, M. Ruckelshaus, D. Skelly, H. Wilbur, K. Zamudio, and NCEAS HCP working group. 1999. Using science in habitat conservation planning. National Center for Ecological Analysis and Synthesis, University of California, Santa Barbara, California, USA.

Langpap, C., and J. Kerkvliet. 2012. Endangered species conservation on private land: assessing the effectiveness of habitat conservation plans. Journal of Environmental Economics and Management 64:1-15. https://doi.org/10.1016/j.jeem.2012.02.002

McKenney, B. A., and J. M. Kiesecker 2010. Policy development for biodiversity offsets: a review of offset frameworks. Environmental Management 45:165-176. https://doi.org/10.1007/ s00267-009-9396-3

Mealy, S. P., J. W. Thomas, H. J. Salwasser, R. E. Stewart, P. J. Balint, and P. W. Adams. 2005. Precaution in the American Endangered Species Act as a precursor to environmental decline: the case of the Northwest Forest Plan. Pages 189-204 in R. Cooney and B. Dickson, editors. Biodiversity and the precautionary principle: risk and uncertainty in conservation and sustainable use. Earthscan, London, UK.

Mitchell, A. 1999. The ESRI guide to GIS analysis. Volume 1. ESRI Press, Redlands, California, USA.

National Research Council. 1995. Science and the Endangered Species Act. National Academy Press, Washington, D.C., USA. 
Natural Community Conservation Planning Act (NCCPA). 1991. California Fish and Game Code. Section 2800 et seq., as amended 2003. California Department of Fish and Wildlife, Sacramento, California, USA.

Noss, R. F., M. A. O'Connell, and D. D. Murphy. 1997. The science of conservation planning: habitat conservation under the Endangered Species Act. Island, Covelo, California, USA.

Pollak, D. 2001. Natural Community Conservation Planning (NCCP): the origins of an ambitious experiment to protect ecosystems. Part 1 of a series. California Research Bureau, Sacramento, California, USA. [online] URL: https://nrm.dfg.ca. gov/FileHandler.ashx?DocumentID $=6388$

Powell, R. B. 2010. Developing institutions to overcome governance barriers to ecoregional conservation. Pages 53-66 in S. C. Trombulak and R. F. Baldwin, editors. Landscape-scale conservation planning. Springer, New York, New York, USA. https://doi.org/10.1007/978-90-481-9575-6 4

Presley, G. L. 2011. California's Natural Community Conservation Program: saving species habitat amid rising development. Pages 115-144 in K. Arha and B. H. Thompson, editors. The Endangered Species Act and federalism: effective conservation through greater state commitment. Routledge, New York, New York, USA. https://doi.org/10.4324/9781936331857

Rohlf, D. 1991. Six biological reasons why the Endangered Species Act doesn't work - and what to do about it. Conservation Biology 5(3):273-282. https://doi.org/10.1111/j.1523-1739.1991.tb00139. $\underline{\mathrm{X}}$

Rohlf, D. 2001. Jeopardy under the Endangered Species Act: playing a game that protected species can't win. Washburn Law Journal 41:114-158.

Rose, J. P., J. S. M. Ersan, G. A. Reyes, K. B. Gustafson, A. M. Fulton, K. J. Fouts, R. F. Wack, G. D. Wylie, M. L. Casazza, and B. J. Halstead. 2018. Findings from a preliminary investigation of the effects of aquatic habitat (water) availability on giant garter snake (Thamnophis gigas) demography in the Sacramento Valley, California, 2014-17. Open-File Report 2018-1114. U.S. Geological Survey, Reston, Virginia, USA. https://doi. org/10.3133/ofr20181114

Schumer, G., E. C. Hansen, P. J. Anders, and S. M. Blankenship. 2019. Development of a quantitative polymerase chain reaction assay and environmental DNA sampling methods for giant garter snake (Thamnophis gigas). PLoS ONE 14(9):e0222493. https:// doi.org/10.1371/journal.pone.0222493

Scott, J. M., D. D. Goble, A. M. Haines, J. A. Wiens, and M. C. Neel. 2010. Conservation-reliant species and the future of conservation. Conservation Letters 3: 91-97. https://doi. org/10.1111/j.1755-263X.2010.00096.X

Scott, T. A., L. Fernandez, and M. F. Allen. 2006. Land use planning. Pages 206-217 in J. M. Scott, D. D. Goble, and F. W. Davis, editors. The Endangered Species Act at thirty. Volume 2. Island, Covelo, California, USA.

Stanford Environmental Law Society. 2001. The Endangered Species Act: a Stanford environmental law society handbook. Stanford University Press, Stanford, California, USA.
Theobald, D. M., N. T. Hobbs, T. Bearly, J. A. Zack, T. Shenk, and W. E. Riebsame. 2000. Incorporating biological information in local land-use decision-making: designing a system for conservation planning. Landscape Ecology 15:35-45. https://doi. org/10.1023/A:1008165311026

Underwood, J. G. 2011. Combining landscape-level conservation planning and biodiversity offset programs: a case study. Environmental Management 47:121-127. https://doi.org/10.1007/ s00267-010-9589-9

U.S. Fish and Wildlife Service (USFWS). 2017. Recovery plan for the giant garter snake (Thamnophis gigas). U.S. Fish and Wildlife Service, Pacific Southwest Region, Sacramento, California, USA.

U.S. Fish and Wildlife Service (USFWS) and National Marine Fisheries Service (NMFS). 2016. Habitat conservation planning and incidental take permit processing handbook. U.S. Department of the Interior, Fish and Wildlife Service, U.S. Department of Commerce, National Oceanic and Atmospheric Administration, National Marine Fisheries Service, Washington, D.C., USA.

Wylie, G. D., M. L. Casazza, C. J. Gregory, B. J. Halstead. 2010. Abundance and sexual size dimorphism of the giant garter snake (Thamnophis gigas) in the Sacramento Valley of California. Journal of Herpetology 44(1):94-103. https://doi.org/10.1670/08-337.1 